\title{
Extracellular Matrix-Associated Pathways Promote the Progression of Gastric Cancer by Impacting the Dendritic Cell Axis [Corrigendum]
}

\author{
Wang Z, Wang Z, Hu X, Han Q, Chen K, Pang The authors apologize for this error. \\ G. Int J Gen Med. 2021;14:6725-6739.
}

The authors have advised there is an error in the author list on page 6725. The author name "Zhenlin Wang" should read "Zhenglin Wang".

\section{Publish your work in this journal}

The International Journal of General Medicine is an international, peer-reviewed open-access journal that focuses on general and internal medicine, pathogenesis, epidemiology, diagnosis, monitoring and treatment protocols. The journal is characterized by the rapid reporting of reviews, original research and clinical studies across all disease areas. The manuscript management system is completely online and includes a very quick and fair peer-review system, which is all easy to use. Visit http://www.dovepress.com/ testimonials.php to read real quotes from published authors. 